\title{
The Song of the Sirens
}

\author{
Karl-Heinz Frommolt and Martin Carlé
}

\begin{abstract}
A B STR ACT In Homer's account of the adventurous journey of Odysseus, the song of the sirens was so appealing and tempting that it lured sailors to their deaths. Warned by the goddess Kirke, Odysseus overcame the trap by plugging his crew's ears with wax.

An archaeo-acoustical research expedition undertaken by members of Humboldt University Berlin made sound propagation experiments at the supposedly historical scene at the Galli Islands where it's said that the sirens originally sung. At the site we broadcasted both synthetic signals and natural voices via loudspeakers in the direction Odysseus most probably should have approached the Siren's island. Subjective listening as well as objective acoustic analysis of the recorded signals revealed evidence for a combination of site-specific acoustic effects which may explain the nature and origin of the song of the sirens in Homer.

The local arrangement of the three islands deforms the acoustic signals by amplification and by changes in timbre. Two female singers from the Berlin State Opera were asked to sing differently pitched musical intervals to be tested in the Li Galli environment. The experiment evinced that the first overtones (octave, fifth, and fourths) would be merged by the echo of the rocks; yet when singing pure thirds and less consonant intervals, which yield higher orders in the overtone series, the voices appear recognisable as being two. As a result, and particularly because Homer stresses the number of exactly two sirens several times, the evidence of our research supports the musicological theory for a rather early existence of enharmonic tunings and most prominently a two-part polyphonic singing of Greek songs. Given that the rocky formation of the Galli Islands most likely didn't change during the geological tick of just 2,700 years, we conclude that there has been a real acoustic basis for the myth reported by Homer and that a "song of the Sirens", most probably based on natural voices, was transformed by the particular acoustic conditions of the landscape in such a way that signals were amplified and sent out in one concrete direction. Based on these results, we continue to discuss further leading acoustic theories that offer new insights into the mythology and which were essential to motivate our expedition in the first place. After all, the question remains open what kind of beings the first emitters of the song might have been.

KEYWORDS acoustic archaeology, Greek mythology, Odyssey, Sirens, ancient Greek music, sound propagations, enharmonic music, diaphony
\end{abstract}

\section{Introduction}

Come hither, as thou farest, renowned Odysseus, great glory of the Achaeans; stay thy ship that thou mayest listen to the voice of us two. For never yet has any man rowed past this isle in his black ship until he has heard the sweet voice from our lips. Nay, he has joy of it, and goes his way a wiser man. For we know all the toils that in wide Troy the Argives and Trojans endured through the will of the gods, and we know all things that come to pass upon the fruitful earth. ${ }^{1}$

With this promise of wisdom and "enjoyment to one's heart's content" $(\tau \dot{\varepsilon} \rho \psi(\varsigma)$, the sirens not only called for Odysseus but for all famed men who were responsible for preserving historical and cultural knowledge. 
As it is widely accepted among philologists and in most cultural theories, amongst them Adorno's world-famous interpretation of the song of the sirens in the "Dialectic of Enlightenment", the songs of Homer belong to oral poetry, but not to literature or even to novels. Since oral poetry is a powerful memorising technique, connections to actual historical events are expectable and far more likely than in pure fiction, how else would Troy ever have been unearthed? Greek Bards (Aoidoi) used to call to the muses in order to get possessed and to subsequently lend their voices to them which altered the state of mind quite significantly. As a consequence, communication and engagement with super-natural voices must be regarded as a common phenomenon and took up a position of empirical truth. Still, we can observe a striking difference when comparing the Iliad to the Odyssey: the latter appears far more consciously arranged and gods and goddesses, known to give immediate audible orders, stopped to send authoritative "advices" by invoking acoustic hallucinations whereas in the former, this was frequently the case. ${ }^{3}$

We argue that both of the above differences have one common reason and can be well explained by tracing the invention of the vocal alphabet taking place in between. This view is supported by the philologist Berry Powell who provides strong evidence that the exceptional feature of Greek writing as a vocal-based alphabet rather than just another syllabic script is due to the extraordinary richness of vowels in Greek tongues and in the strongest, historically and locally concrete thesis, that the phonetic alphabet was called into being at Euboia about 80o BC for the very and only occasion to record the beauty of Homer. ${ }^{4}$

Whether one is willing to follow the weaker or the stronger thesis, it remains justifiable to search for traces of the real in the later Homeric Epos, even if the Odyssey is lesser a divine dictation and more a hand edited manuscript. Moreover, if we assume such a reflective use of the vowel alphabet while composing the Odyssey, this allows us for the first half of the paper to even strengthen our arguments from sides of acoustic theory and to now pose the hypotheses that (i) the song of the sirens was itself a self-aware coding of the media change from oral poetry to scriptaided compositions and (ii) that the most elaborate acoustical scene that one can find in Homer is grounded on aspects of real acoustical phenomena that may be re-discovered and located at a specific geological site.

The second half of the paper will expand on the first point and bring in more resonance from poetry and further musicological echoing. But before this can happen, the actual measured evidence of the second point shall be put forth. For this reason the present introductory section closes 
by quoting the accurate and concrete conditions that Homer describes and likewise prescribe the constraints to be met by any acoustic archaeology of the siren's song:

Meanwhile the well-built ship speedily came to the isle of the two Sirens for a fair and gentle wind bore her on. Then presently the wind ceased and there was a windless calm, and a god lulled the waves to sleep. ${ }^{5}$

\section{Sound Propagation Experiments}

Sound propagation experiments were conducted at the Galli Islands, located on the Amalfi coast in Central Italy (40 $\left.34^{\prime} 57^{\prime \prime} \mathrm{N}, 14^{\circ} 26^{\prime} \mathrm{O} 3^{\prime \prime} \mathrm{E}\right) 15 \mathrm{~km}$ east from the island of Capri. Strabo records that this formation of rocks has been known as the Sirenussae, the Island of the Sirens. ${ }^{6}$ More recent attempts to reconstruct the possible route of Odysseus based on the rather detailed descriptions of landmarks by Homer and on realistic travelling distances for ancient Greek navigators support this hypothesis. ${ }^{7}$ The Galli Islands consist of three small rocky islets with steep slopes (Gallo Lungo, La Castellucia and La Rotonda) (fig. 1). We broadcasted synthetic (white noise) and natural signals (human singers' voice and calls of monk seals). Two trained human voices sung glissandi and chanted intervals of vowels previously recorded on tape. In addition, recordings of monk seals were used for several reasons. We did not want to rule out the possibility that an acoustic event other than a female voice could have been the origin of the Sirens' song. Monk seals are the only amphibious mammals in the Mediterranean. Nowadays this species is very rare but it was common in the region in historic times. Moreover, similarities in the anatomy of the vocal tract result in vocalisations which can easily be associated with the human voice rather than bird sounds.

The loudspeakers, a F2 Martin audio-system, was placed at Gallo Lungo near the shoreline at $2 \mathrm{~m}$ above sea level. The distance from the loudspeaker to La Castellucia and La Rotonda was approximately 350 m (fig. 2). The sound pressure level of the emitted sounds was approximately $140 \mathrm{~dB}$ at $1 \mathrm{~m}$ distance.

The sounds were recorded out at sea from a rowboat propelled by an outboard motor. To capture them, we moved along a route in eastern direction from Gallo Lungo and entered the passage between La Castellucia and La Rotonda. At five positions we stopped our boat's engine and recorded the repeatedly emitted sounds which we had prepared. The nearest point was approximately $150 \mathrm{~m}$ from the loudspeaker, the most distant point was $500 \mathrm{~m}$. Recordings were made with a Tascam DA-P1 

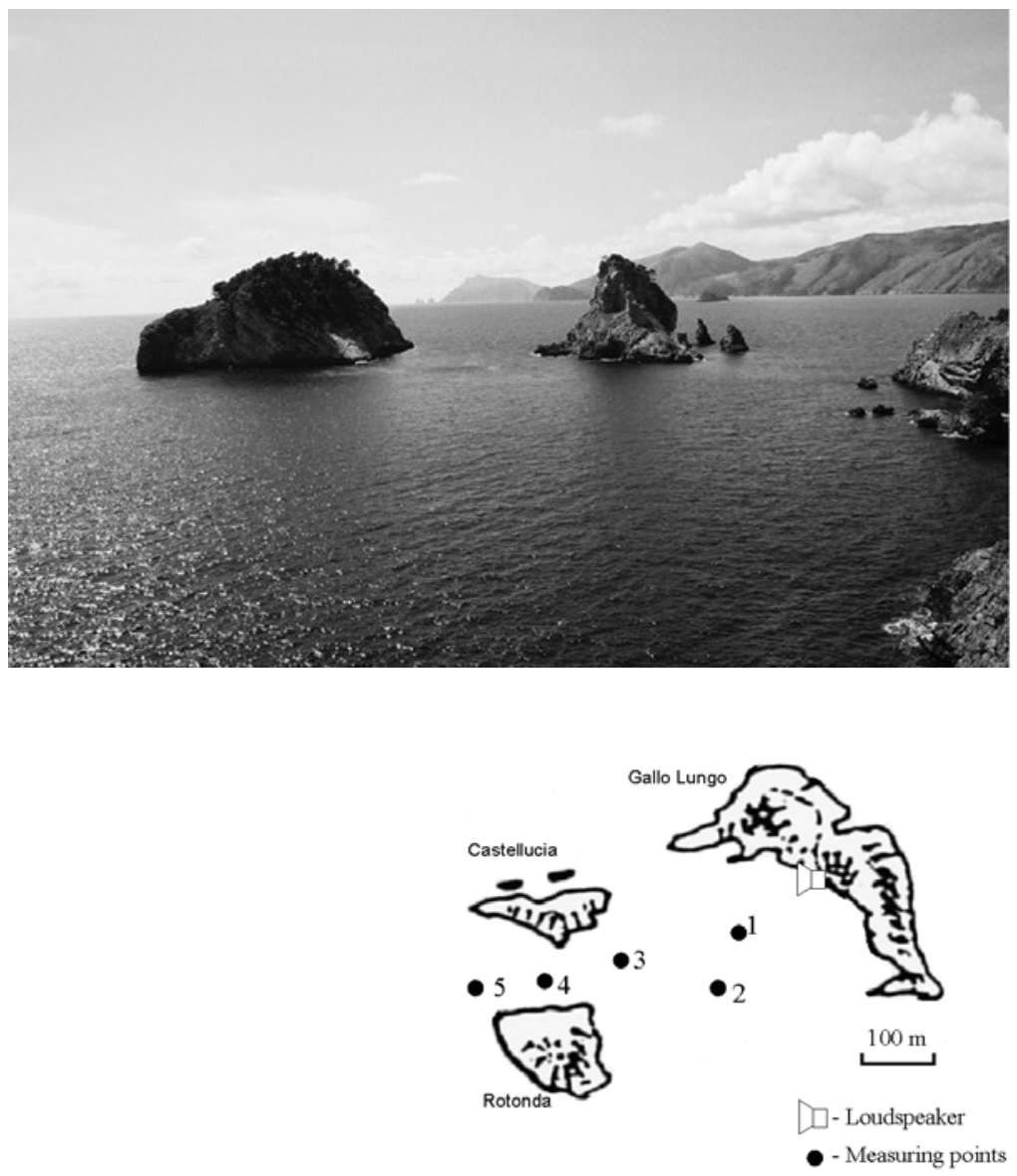

Fig. 1. The Li Galli Islands at the Amalfi coast in Central Italy. View from Gallo Lungo to the island Capri. The two isles in the front are La Rotonda (left) and La Castellucia (right) (Photo K.-H. Frommolt).
Fig. 2. Schematic view of the Li Galli islands with the trajectory used for sound transmission experiments. The signals were broadcasted from a point approximately two meters above the shoreline. The transmitted signals were recorded from a small rowboat. 
DAT-Recorder equipped with a Brüel and Kjaer microphone Type 4011 and an omnidirectional electret microphone Sennheiser MKE 2-P mounted in a funnel. For all takes the recording level was kept constant. During our experiments we had moderate sea disturbances and surf noise. To counter it, one microphone mounted in the funnel acted as a high pass filter, reducing the low frequency disturbances caused by surf.

For analysis the recorded sounds were transferred to wave files using a sound card with digital input (RME digig6/8 pad). Acoustic measurements were made with SASLab Pro (Avisoft) software.

\section{Results of the Acoustic Experiments}

Since weather conditions in early April were far from optimal for our experiments and the exact coordinates of the boat's measurement position could only be estimated through bearing, we will focus on a qualitative assessment of the measures. Nevertheless with both, synthetic and natural signals, we found the same effect, 'distinct and clear' to ours and even the boatsman's ears.

The white noise signal recorded between the two smaller islets showed higher amplitudes in the $1,000-5,000 \mathrm{~Hz}$ frequency range than the same signal recorded just in front of the islands (fig.3). The natural signals (human voices and seal calls) were louder at the positions between and just behind the two smaller islands (positions 4 and 5) than just in front of them (position 3) (fig. 4). This result can be seen clearly in the lower harmonics where the main energy of sound is located. The changes in loudness were distinctly perceived even to the naked ear. Our results lead to the conclusion that the specific geographical constellation of the island acts as an acoustic amplifier between La Castellucia and La Rotonda in the direction towards Capri.

Regardless of the fact that in our experiments we used an unnaturally high sound pressure level (which was necessary and chosen preemptively to overcome the noise of surf), we certainly expect that the same results would be obtained with natural human voices and natural monk seal calls under conditions Homer described quite accurately in Song 12. A "windless calm" and "sleeping waves" are optimal conditions for sound propagation. Giving spherical spreading of sound we would expect a decrease of sound pressure level of $52 \mathrm{~dB}$ over a $400 \mathrm{~m}$ distance. In the frequency range up to $2 \mathrm{kHz}$ attenuation due to absorption would be less than $6 \mathrm{~dB}$ for the same distance $\left(13,8 \mathrm{~dB} / \mathrm{km}\right.$ for $2 \mathrm{kHz}$ at $30^{\circ} \mathrm{C}$ and 90 percent relative humidity $)^{8}$. For the voice of the two sopranos we estimated a sound pressure level of $100 \mathrm{~dB}$ at $1 \mathrm{~m}$ distance. Our rather con- 
Fig. 3

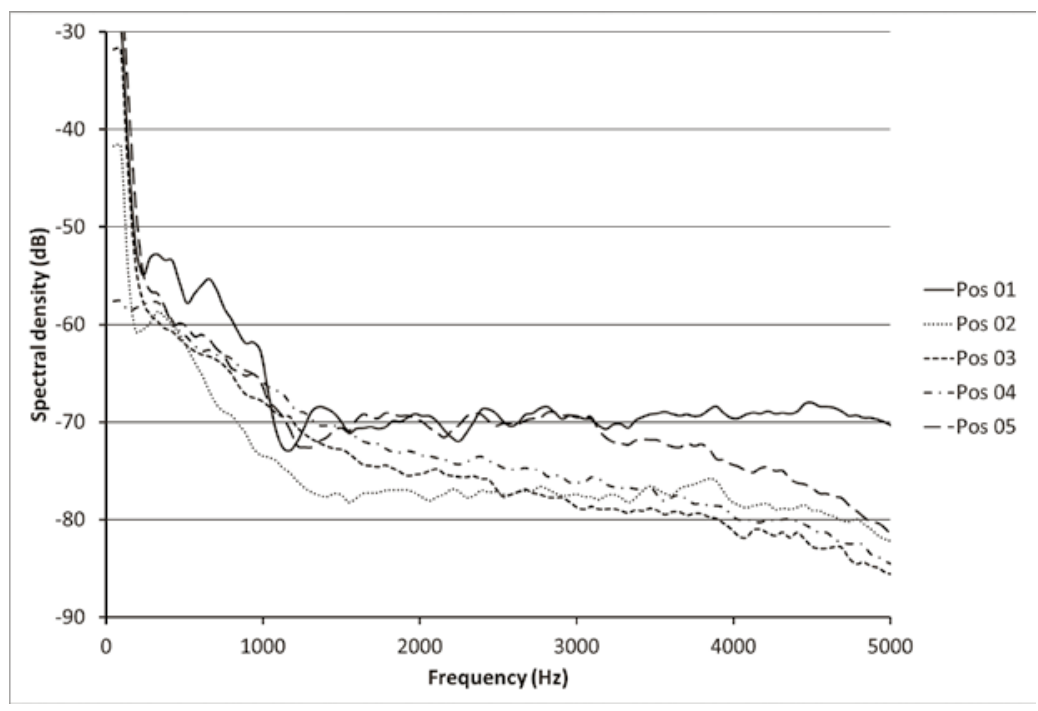

Fig. 4

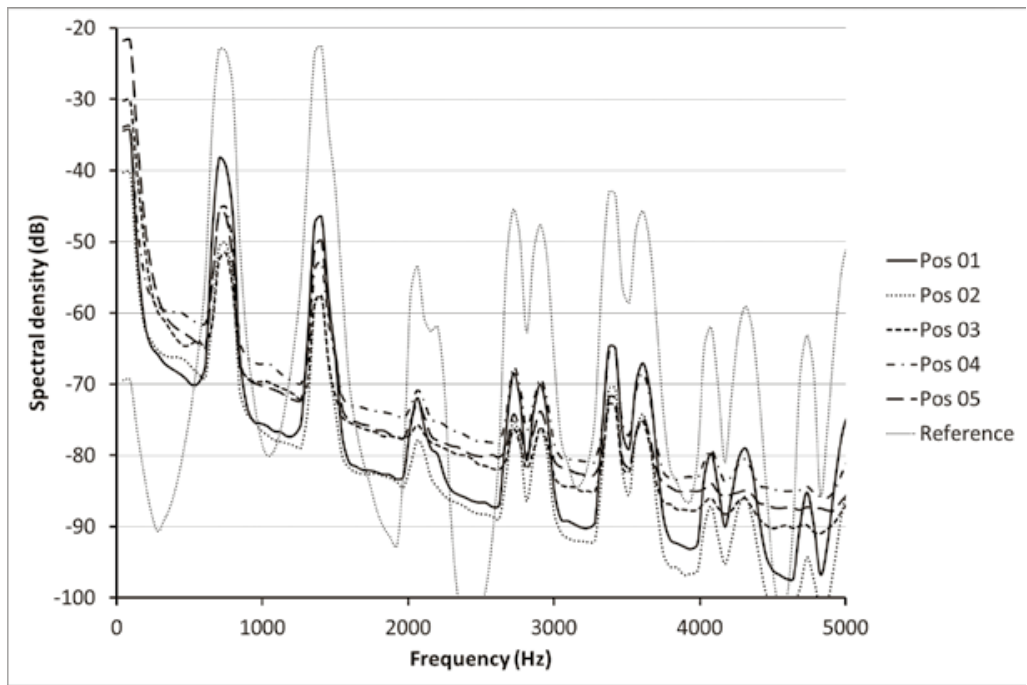

Fig. 3. Mean power spectra of white noise broadcasted from the loudspeakers and recorded at different places (according to fig. 2). Over a wide frequency range the sound pressure level is higher at the two most distant positions than at the two midrange positions. High amplitudes in the frequency rang below $200 \mathrm{~Hz}$ are mostly caused by surf noise.

Fig. 4. Spectrograms (upper part) and mean power spectra for the two sopranos. The spectrogram was calculated from the original signals (FFT settings: sampling rate $16000 \mathrm{~Hz}$, FFT size 512, Hann window). The spectra were calculated for the signals recorded at the five measuring positions (FFT settings: sampling rate $48000 \mathrm{~Hz}$, FFT size 1024, Hann window). A clear amplification effect at frequencies between 500 and $2000 \mathrm{~Hz}$ was discovered at the positions 4 and 5 . The dotted line presents the power spectrum of the original signal. 
servative calculation would lead to the conclusion that in quiet weather conditions this song should have a sound pressure level of at least $42 \mathrm{~dB}$ at a distance of $400 \mathrm{~m}$.

Since we know that in Homer there were no serious surf noises and the influence of wind may be neglected, in reality the sound pressure level would have been even higher. Sound travels through different pathways and especially downward refraction can amplify its reach and range considerably. This natural phenomenon occurs when temperatures in lower air layers are lower than in higher layers, a typical situation above water surfaces in summer time!

Listening to Homer, Odysseus arrived in early summer at "the wondrous Sirens, and their flowery meadow". ${ }^{9}$ Hence the least we shall say is that even human voices would be strong enough to travel from Gallo Lungo to the observed acoustic amplifier. Under conditions described in the Odyssey they would spread out quite far and, despite any invisibility of the sound source, could easily be perceived by the human ear, since the lowest reasonably estimated sound pressure level of $42 \mathrm{~dB}$ is much higher than the hearing threshold in humans. ${ }^{10}$ As a consequence, the limiting factor for sound perception mostly depends on the level of background noise. Although we have no data on sound intensity of monk seals, we can expect that the calls of these large mammals are much louder than human songs. Domestic dogs, for example, bark at an estimated sound pressure level in the range of about $115 \mathrm{~dB}$ at $1 \mathrm{~m}$ distance. ${ }^{11}$

No matter if human or mammalian voices were involved, both would be equally amplified. The amplification effect can be physically explained by reflections from the rocky walls at the specific site. The overall acoustic event will be the sum of direct sound waves and sound waves reflected from the rocks. Unfortunately the weather conditions did not allow us to make measurements at more distant points and forced us to return to the main island.

By common sense the two rocky islets, La Rotonda and La Castellucia, should rather be seen as a barrier for sound. But given the reconstructed route by Ernle Bradford, ${ }^{12}$ Odysseus and his fellows approached the Siren island from Capri, the very direction in which the 'natural megaphone' of Li Galli would cast any sound coming from Gallo Lungo near the shoreline. Lured by this sound-beam and finally arriving at the narrow rocky passage towards the beautiful flourishing main island (which promises fresh, sweet water), navigation would surely become critical and dangerous - no matter what possibly unidentifiable sound source caused the sailors' concentration to lapse, whether the sounds were perceived as 
real or hallucinations, and whether they originated from females, monk seals, sirens or super-naturals. Spectral comb-filter effects due to reflections shape voices at site to sound unnatural or even miraculous, as all of us who visited that island would affirm.

\section{The Sirens' Song and Musical Intervals}

It is not the first time by far that a close connection has been drawn between the siren mythology and music theory in ancient Greece. Most familiar might be the notorious 'harmony of the spheres' where a siren sits on each of the celestial spheres around "the spindle of Necessity" constantly sounding one particular tone of a ratio-divided octave with her voice. ${ }^{13}$ Plato's metaphors derived from original Pythagorean mathematics are carried further in the Timaeus where explicit harmonic relations of intervals shall resemble the "World-Soul" as a likewise proportional and ethical structured universe fashioned by his Demiurge. ${ }^{14}$ But despite such cosmological projections in the heavens the chtonic origin of the sirens and their earth-bound wisdom still sound through. Even Plato's idealism did not dare to alter their Homeric characterisation - "for we know all the toils that [...] endured [...] and we know all things that come to pass upon the fruitful earth"15 - since there are still the three other

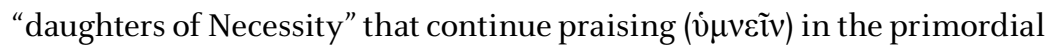
"harmonia of the sirens": "Lachesis singing the things that were, Clotho the things that are, and Atropos the things that are to be." ${ }^{\text {"6 }}$

Together this musical arrangement counts eleven tones, the very cardinal number that already Alcman, long before Plato, used as an argument for the "divine" and "clear-voiced" Sirens to be "more musical" than other female choirs consisting of only ten. ${ }^{17}$ Also Martin West, in his philological search for the historical course of the Greek "struggles" to fix similar modal scales towards a canonical musical system of reference, considers Alcman's testament to be "the earliest fragment of evidence" for this standardisation process. He draws a straight line to the telling Pythagorean acousmata that asks: "[What is the oracle at Delphi?] The Tetraktys, which is the harmony in which the Sirens are."18

Yet the Tetraktys, while having "the Sirens in it", is not simply about small number relations or merely metaphysical speculation. According to Johannes Lohmann it was nothing less than a "mathematical operator"19 leading the Greeks to their calculus of fractions and a methodological understanding of the world centered on logos and harmony. Moreover, Árpád Szabó points out that in contrast to a phenomenological representation of intervals to the ears, the operations of multiplication and divi- 
sion of musical intervals was only necessary to be performed in order to represent the acoustical, physical domain of sound by ratios, afterwards codified as the pre-Euclidean theory of proportions. ${ }^{20}$ Finally following Martin Vogel, the Tetraktys was enough to mathematically synthesise all fixed intervals of the "perfect system" in early Greek musical theory. ${ }^{21}$ In regards to the anatomy of the latter scale that eventually settled as "perfect" and the henceforth canonical scale construction, the number eleven gains high significance as a firm musicological reference.

Against this backdrop, the reader may follow our assumption that referring to 'the sirens' in musico-poetical contexts most likely goes beyond the metaphorical level and to be convinced that a specific pitch-relation of the sirens' voices can "represent the true, perfect sound that Alcman desired". In all likelihood, provided the poet of the 12th song does reflect upon his own art, it should be reasonable to look for further evidence and to bring in a technique of investigation that is able to reach beyond the philologists' traditional methods. All the more so, if we recall that 'sirens' like muses to minds of oral poetry were entities of real experience and that the very nature of their existence supplied wisdom from within and through the audible domain. What then might the so prominently repeated casus dualis ${ }^{22}$ of exactly two sirens in the Odyssey and at Li Galli account for?

\section{Enharmonic Tuning and Early Diaphony in Ancient Greece}

In compliance with later theory there is only one way to divide the octave in eleven tones, namely in taking two tetrachords (fourths), once conjunct by the middle tone, once disjunct by a tone (9:8). This standard procedure yields eleven notes, if and only if the tetrachords themselves are tuned enharmonically (fig. 5)! Laxly said, tuning a tetra-chord enharmonically means to take a big step of about two tones from 'above' the fourth and fill the remaining 'bottom' with two 'micro-tones'. To be sure, whether the resulting characteristic from the now on focused interval of the enharmonic 'genus' is tuned 'mathematically' to a real ditone (9:8 $\times 9: 8=81: 64)$ like in Philolaos B6, or whether it was sensually "sweetened" 23 towards the little smaller pure third (5:4) in order to be more 'harmonically' in tune like in Archytas A16, cannot be verified empirically through resonance experiments at Li Galli. Yet the term 'en-harmonic' - literally meaning in-(real)-harmony - suggests a preference of pure, acoustically non-beating intervals as these intervals are naturally present in the overtone series $(1: 2,2: 3,3: 4,4: 5,5: 6, \ldots)$. But in either case, 'deeplistening' to the musical 'sonosphere' and testing intervals against their 
The Song of the Sirens

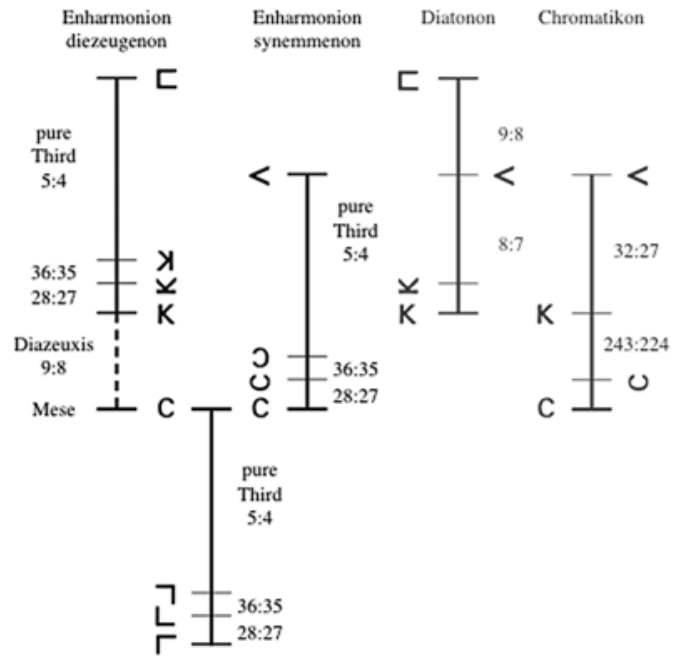

Fig. 5. Early enharmonic tuning in ancient Greek instrumental notation that yields 11 tones within the octave. The ratios are taken from Archytas A 16. 
beating is an aesthetic prerequisite to any acoustic reasoning that arrives at numbers and that eventually inducts an epimoric $((n+1): n)$ building principle for musical intervals, like the Pythagoreans did.

By all means, irrespective of the number eleven that led us to assume an en-harmonic context for the sirens in the first place and entirely independent from overtone theory not available to the Greeks, both audible phenomena - beating and the superposition of intervals - did nonetheless rule upon acoustical process in the ancient times as well as over the multiple reflections observable at Li Galli today. Another self-evident premise for reasonable experiments with musical intervals at site is that the notes in question must have been sounded simultaneously. Otherwise, when given in succession like in the platonic siren metaphor as highlighted by Barker, ${ }^{24}$ no enharmony nor cacophony would ever occur. Finally the presumption of an early Greek two-part polyphonic singing (diaphony) is justified by the most trustworthy report about the origin of enharmony that we possess and that has been ascribed to Aristoxenus of Tarentum, ${ }^{25}$ the greatest musicological authority of the ancient world. Regarding this report, most relevant to our context appears that it was a Phrygian double-aulos player, Olympus, who invented nomoi and melodies which made first use of the characteristic enharmonic interval within a pentatonic scale (meaning a scale without any 'micro-tones') and that only later on he applied the melodic characteristics of his discovery in the Dorian mode. Ultimately, when thinking of the physical conditions of having two pipes of unequal length in one mouth, it is simply natural that an accompaniment to melodies will be arranged by two notes sounding together, simultaneously emitted from both pipes. For a virtuoso player like Olympus, we can be close to certain that he sought to bring out the beauty of the pure, non-beating third and that he attempted to preserve the newly yielded ethos of his melodies in other modes thereby 'inventing' what become known as the Greek enharmony. ${ }^{26}$

\section{Acoustic Evidence}

As a matter of fact, to conclude, intervals given together by two voices at Li Galli can only be differentiated as being 'accords', that means having two separate sources, if their overtone structures do not merge. Our experiments showed that octaves, fifths and fourths were melting indistinguishable into each other, whereas at first with the third and all further less 'consonant' intervals, whilst counting up the overtone series, did preserve the identity of separate harmonic sound generators.

Because the pure major and minor thirds are frequent and typical for 
enharmonic scales and less 'consonant' intervals are not likely to be of great use for any harmonic accompaniment, our finding adds to the evidence that (i) thirds are the characteristic intervals of enharmonic tuning in Ancient Greece and (ii), more importantly, that Greek enharmony has been developed from an early diaphony for which, next to the doubleaulos, now the casus dualis in the song of the two sirens holds.

But if thou thyself hast a will to listen, let them bind thee in the swift ship hand and foot upright in the step of the mast, and let the ropes be made fast at the ends to the mast itself, that with delight thou mayest listen to the voice of the two Sirens. ${ }^{27}$

If we believe Aristoxenus that by invention of the enharmonic Olympus become "'archegos' of the Hellenic and beautiful music" 28 and if we are willing to appreciate that the ditone "far from being the most contemptible is perhaps the finest", ${ }^{29}$ we shall also take into account that etymologically "Zeirene as Seirenes stems from $\chi \alpha$ ápı, the word for grace and gratifying itself" and that "Zeirene in singular form means utterly Aphrodite, goddesses of all love and desire". ${ }^{30}$

'Deep Listening' then, in the ancient sense of getting to know through music indivisibly goes along with $\tau \dot{\varepsilon} \rho \psi \imath \varsigma$ - since "with delight, cheer, and satisfaction"31 you mayest listen to the voices of us two. Sanctuaries of the Sirens are spread all along the Amalfi coast near Li Galli and the sirens' promise, indeed, can only be heard and sung further, if Odysseus actually 'stayed his ship' at their island despite all the 'warning' jealousy of Kirke only seeking to prevent just this to happen. As a consequence, the present archaeo-acoustic, more literal than literate understanding of the song of the sirens supports Aphrodite granting to please Odysseus' desire and withdraws Adorno's modern dialectic of enlightenment as much as any ideas of sirens in platonic sense. ${ }^{32}$

To summarise, our results support the hypothesis that the Song of the Sirens in Homer's epic is based on a real acoustic event at Li Galli. The casus dualis of Homer's Sirens can be acoustically motivated by the musicological hypothesis of an early Greek diaphony grounded in enharmony. The quest, however, what kind of beings or what exactly emitted the extolled sirenic sounds among the Galli islands cannot be decided on basis of the currently obtained measurements. As a desideratum remains the collection of more quantitative data recorded from better suited voices which in turn would entail a further developed 'acoustical reasoning' and enough time for a deeper listening at site. 


\section{Acknowledgements}

Our studies in Acoustic Archaeology were embedded in an acousticalarchaeological research expedition organized by Prof. Wolfgang Ernst, after an initiative of Prof. Friedrich Kittler and Christian von Borries. We are much indebted to Mr. Giovanni Russo, the owner of the Galli Islands, for permission and support of our venture. Our experiments could not have been carried out without the dedicated support of boatsman Cataldo Persico, the chargehand of the islands, and his two philippine assistants. Special thanks go to Luise Schumacher and Kath Mullins who gave the sirens a natural voice and 'Max und Moritz' from PAM/events Berlin who made them strong. Thanks to Richard Ranft from The British Library Sound Archive for providing us with recordings of monk seals and for help with the manuscript.

\section{Notes}

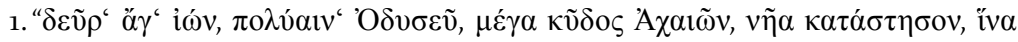

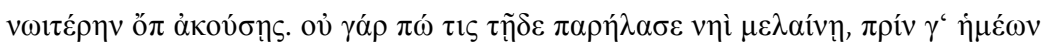

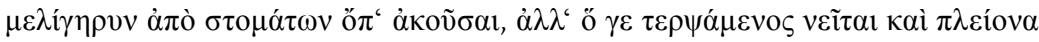

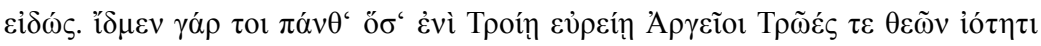

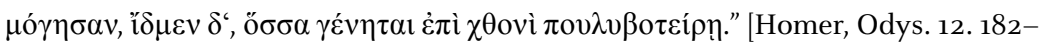
91].

2. Max Horkheimer and Theodor W. Adorno, Die Dialektik der Aufklärung (Amsterdam: Querido, 1947).

3. Cf. Julian Jaynes, The Origin of Consciousness in the Breakdown of the Bicameral Mind (Boston: Houghton Mifflin, 1976).

4. Barry B. Powell, Homer and the Origin of the Greek Alphabet (Cambridge: Cambridge University Press, 1991).

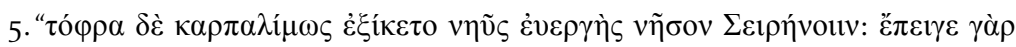

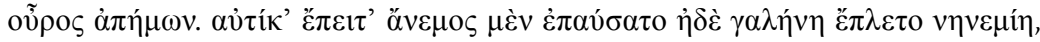

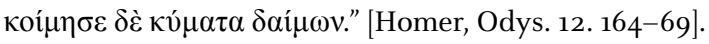

6. Strabo, Geographica, ed. A. Meineke (Leipzig, 1877). Trans. H.L. Jones, The Geography of Strabo (Cambridge, Mass.: Harvard University Press, 1924), 1.2.12-13.

7. Ernle Bradford, Ulysses Found (London: Reader's Union, 1964); Armin Wolf and Hans Helmut Wolf, Die wirkliche Reise des Odysseus (München: Langen Müller, 1983).

8. Louis C. Sutherland and Gilles A. Daigle, "Atmospheric Sound Propagation", in Handbook of Acoustics, ed. M. J. Crocker (New York: Wiley, 1998), 305-29.

9. Homer, The Odyssey, with an English Translation by A.T. Murray, Ph.D. in two vols. (Cambridge, MA: Harvard University Press, 1919), 12.159. 
10. Bert Scharf, "Loudness", in Handbook of Acoustics, ed. M. J. Crocker (New York: Wiley, 1998), 1181-95.

11. Karl-Heinz Frommolt and A. Gebler, "Directionality of Dog Vocalization", The Journal of the Acoustical Society of America 116 (2004), 561-65.

12. Bradford, Ulysses Found.

13. Plato, Republic 616c-617d, in Plato, Platonis Opera, ed. John Burnet (Oxford: Oxford University Press, 1903).

14. Plato, Timaeus 34c-36d, in Plato, Platonis Opera, ed. John Burnet (Oxford: Oxford University Press, 1903).

15. Cf. the introductory section above.

16. Plato, Timaeus 34c-36d.

17. Plato, Timaeus 34c-36d.

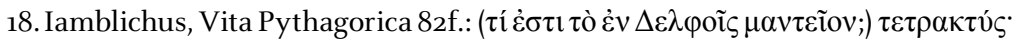

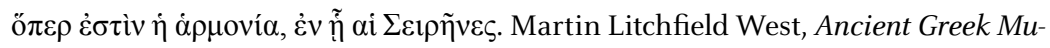
sic (Oxford: Oxford University Press, 1992), 224 reads: "the octave which embodies the fundamental harmonic ratios (1:2,2:3,3:4) 'has the Sirens in it"'.

19. Johannes Lohmann, Musiké und Logos: Aufsätze zur griechischen Philosophie und Musiktheorie, ed. A. Giannarás (Stuttgart: Musikwissenschaftliche Verlags-Gesellschaft, 1970), 74.

20. Árpád Szabó, Die Entfaltung der griechischen Mathematik (Mannheim: Wissenschaftsverlag, 1994), 133-40.

21. Martin Vogel, Die Enharmonik der Griechen, Bd. 1 (Düsseldorf: Gesellschaft zur Förderung der systematischen Musikwissenschaft, 1963), 83-93.

22. Homer, The Odyssey, 12: (I) that with delight thou mayest listen to the voice

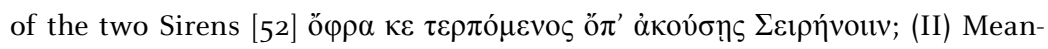

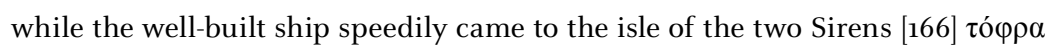

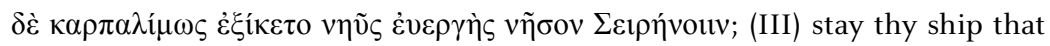

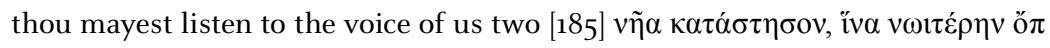

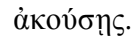

23. Aristoxenus, 23,14, trans. in Greek Musical Writings, vol. 2, Harmonic and Acoustic Theory, ed. Andrew Barker (Cambridge: Cambridge University Press, 1989), 141.

24. Barker, Greek Musical Writings, vol. 2, 58, footnote 11.

25. Aristoxenus, 23, 14, trans. in Barker, Greek Musical Writings, vol. 2, 141.

26. Martin Carlé, "Enharmonische Archäologie der griechischen Musiknotation", in Die Geburt des Vokalalphabets aus dem Geist der Poesie, ed. Wolfgang Ernst and Friedrich Kittler (Munich: Fink, 2006), 281-97: 294-97.

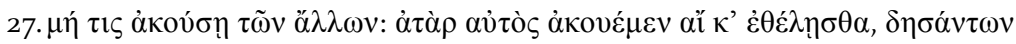

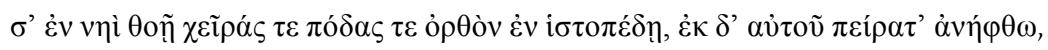

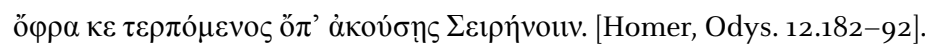


28. Ps.-Plutarch, De musica, 11.

29. Aristoxenus. 23,3, in Barker, Greek Musical Writings, vol. 2, 141.

30. Friedrich Kittler, Mathematik und Musik, I/1 (Munich: Fink, 2006), 44.

31. Henry George Liddell and Robert Scott, An Intermediate Greek-English Lexicon (Oxford: Clarendon Press, 1889).

32. Further elaborations of this point can be found in Martin Carlé, "Sang und Eiland der Sirenen: Reisebericht einer medienarchäologischen Forschungsexpedition“, in Klangräume der Kunst, ed. Peter Kiefer (Heidelberg: Kehrerverlag, 2010), 105-21.

\section{Bibliography}

Alcman, in Poetae Melici Graeci, ed. D. L. Page. Oxford: Clarendon Press, 1962.

Archytas, Archytas of Tarentum, ed. C. Huffman. Cambridge: Cambridge University Press, 2005.

Barker, Andrew, ed. Greek Musical Writings, vol. 2, Harmonic and Acoustic Theory. Cambridge: Cambridge University Press, 1989.

Bradford, Ernle. Ulysses Found. London: Reader's Union, 1964.

Carlé, Martin. "Enharmonische Archäologie der griechischen Musiknotation". In Die Geburt des Vokalalphabets aus dem Geist der Poesie, edited by Wolfgang Ernst and Friedrich Kittler, 281-97. Munich: Fink, 2006.

Carlé, Martin. "Sang und Eiland der Sirenen: Reisebericht einer medienarchäologischen Forschungsexpedition”. In Klangräume der Kunst, edited by Peter Kiefer, 105-21. Heidelberg: Kehrerverlag, 2010.

Ernst, Wolfgang. "Lokaltermin Sirenen oder Der Anfang eines gewissen Gesangs in Europa". In Phonorama: Eine Kulturgeschichte der Stimme als Medium, edited by Brigitte Felderer, 256-66. Karlsruhe. Berlin: Matthes \& Seitz, 2004.

Frommolt, Karl-Heinz and A. Gebler. "Directionality of Dog Vocalization", The Journal of the Acoustical Society of America 116 (2004), 561-65.

Homer. The Odyssey with an English Translation by A.T. Murray in two vols. Cambridge, MA: Harvard University Press, 1919.

Horkheimer, Max and Theodor W.Adorno. Die Dialektik der Aufklärung.

Amsterdam: Querido, 1947.

Iamblichus. De vita Pythagorica. In On the Pythagorean Way of Life, edited by John Dillon and Jackson Hershbell. Atlanta: Scholar's Press, 1991.

Jaynes, Julian. The Origin of Consciousness in the Breakdown of the Bicameral

Mind. Boston: Houghton Mifflin, 1976.

Kittler, Friedrich. Mathematik und Musik, I/1. Munich: Fink, 2006.

Liddell, Henry George and Robert Scott. An Intermediate Greek-English Lexicon. Oxford: Clarendon Press, 1889. 
The Song of the Sirens

Lohmann, Johannes. Musiké und Logos: Aufsätze zur griechischen Philosophie und Musiktheorie. Edited by A. Giannarás. Stuttgart: Musikwissenschaftliche Verlags-Gesellschaft, 1970.

Plato, Platonis Opera. Edited by John Burnet. Oxford: Oxford University Press, 1903.

Barry B. Powell, Homer and the Origin of the Greek Alphabet. Cambridge: Cambridge University Press, 1991.

Scharf, Bert. "Loudness". In Handbook of Acoustics, edited by M. J. Crocker, 1181-95. New York: Wiley, 1998.

Strabo, Geographica. Edited by A. Meineke. Leipzig: Teubner, 1877. Translated by H. L. Jones as The Geography of Strabo (Cambridge, Mass.: Harvard University Press, 1924).

Sutherland, Louis C. and Gilles A. Daigle. "Atmospheric sound propagation". In Handbook of Acoustics, edited by M. J. Crocker, 305-29. New York: Wiley, 1998.

Szabó, Árpád. Die Entfaltung der griechischen Mathematik. Mannheim: Wissenschaftsverlag, 1994.

Vogel, Martin. Die Enharmonik der Grieche, vol. 1. Düsseldorf: Gesellschaft zur Förderung der systematischen Musikwissenschaft, 1963.

West, Martin Litchfield. Ancient Greek Music. Oxford: Oxford University Press, 1992.

Wolf, Armin and Hans Helmut Wolf. Die wirkliche Reise des Odysseus. Munich: Langen Müller, 1983. 